\title{
Armed Forces as Security Agency and The Competence of Military Courts: The Prospect of Democratic Breakdown
}

\section{Forças Armadas na Segurança Pública e a Competência dos Tribunais Militares: Possível Rompimento Democrático}

\section{Rodrigo Grazinoli Garrido ${ }^{1}$}

Universidade Federal do Rio de Janeiro - Rio de Janeiro/RJ

grazinoli.forense@gmail.com

http://lattes.cnpq.br/4027138006793482

https://orcid.org/0000-0002-6666-4008

Ana Morell ${ }^{2}$

Universidade Católica de Petrópolis - Petrópolis/RJ

anamorell@me.com

http://lattes.cnpq.br/5703544393321502

http://orcid.org/0000-0003-0821-6941

\section{Silvana Vieira Azevedo ${ }^{3}$}

Universidade Federal do Rio de Janeiro - Rio de Janeiro/RJ silvanaptg@yahoo.com.br

http://lattes.cnpq.br/8274962982068807

http://orcid.org/0000-0002-0575-7067

1 Pós-Doutor em Genética pela UFRJ; Mestre e Doutor em Ciências pela UFRJ e UFRRJ, respectivamente; Jovem Cientista do Nosso Estado - FAPERJ; Professor Adjunto FND-UFRJ e do PPGD-UCP; Perito Criminal IPPGF-PCERJ.

2 Licenciada em Direito pela Universidad de Valencia, com período de intercâmbio na Universidad Johannes Gutenberg de Maguncia, na Alemanha. Mestrado em Ciências Jurídicas pela Stanford University. Doutorado em Direito pela Universidad Carlos III de Madrid. Pos-doutoranda em Direitos Humanos pela CAPES/UCP.

3 Bacharel em Direito FND-UFRJ. 
AвSTRACt: This paper sought to discuss the role of the Armed Forces in Public Security, shedding light mainly on two points: the increased number of military crimes, especially those under Law $n^{\circ}$ $13.4891 / 17$, and the maintenance of jurisdiction in military courts over conflicting parties involved in lawsuits of Law and Order Assurance nature. Therefore, an exploratory and qualitative research was developed based on national and international doctrine and jurisprudence, as well as on the Brazilian legislation. This enabled us to acknowledge that the way and the extent to which the Armed Forces have been employed in Public Safety and in the Brazilian criminal prosecution may result in great risks of damage to human rights and, hence, to democracy.

KeY words: Armed Forces; Public Security; Military Crimes; Jurisdiction to try.

ResUmo: O artigo buscou discutir a atuação das Forças Armadas na Segurança Pública, lançando luz principalmente sobre dois pontos: o aumento no rol de crimes militares, especialmente no que diz respeito à Lei 13.4891/17, e a manutenção em tribunais militares com jurisdicionalidade sobre civis conflitados em ações de Garantia da Lei e da Ordem (GLO). Para tanto, foi desenvolvida pesquisa exploratória e qualitativa, a partir da doutrina e jurisprudência nacional e internacional e da legislação brasileira. Com isso, foi possível reconhecer que na forma e na regularidade em que se tem empregado as Forças Armadas na Segurança Pública e na persecução penal brasileira há grande risco de lesão aos direitos humanos e, assim, à democracia.

Palavras-chave: Forças Armadas; Segurança Pública; Crimes militares; Competência para julgamento.

Contents: Introduction; 1. Criticism on Police Work in Public Safety; 2. Agents of The Armed Forces, the Military Staff; 3. Operations of Law and Order (LAO); 4. Militarization of Public Security and Human Rights; Conclusion; References.

\section{INTRODUCTION}

The Brazilian Armed Forces have been increasingly used to assure the National Public Security. Only in the 2010's, a presidential 
decree created about 50 law-and-order operations, which should be exceptional but became a palliative strategy for continuing problems in the federation units ${ }^{4}$.

Besides the criticism on the preparation of service members to act in direct contact with civilians on the streets, in times of peace, the army's performance in conflicts of public security has generated discussions about the limits of the military penal code and the jurisdiction of the military justice towards civilians, and thus considering the safeguard of human rights and democracy.

Thus, the role of the Army as a Public Security agent has to be investigated to throw light on two issues related to criminal prosecution by military agencies. One problem consists of an increased number of military felonies, especially due to changes in legislation for crimes committed by service members against life in the context of law-and-order (LAO) operations. Moreover, the other comprises the maintenance of military courts with jurisdiction over civilians with military personnel in policing actions of the Armed Forces in peacetime.

In doing so, we developed an exploratory and qualitative research based on documents from secondary sources of national and international legal writings and case law, and from primary sources of Brazilian legislation.

\section{Criticism on Police Work in Public Safety}

For some time, public security has occupied a central space in political debates, following different approaches according with the existing decision-making institutions ${ }^{5}$. Above all, in late modernity, the fear of crime and terrorism has been demanding solutions that are more effective, which is well represented by a constant vigilance ${ }^{6}$.

4 MINISTÉRIO DA DEFESA. DISTRIBUIÇAO DAS OPERAÇÕES DE GLO 1992 - 2018.

5 FABRETTI, Humberto Barrinuevo. Políticas de segurança Pública: questionamentos preliminares. In: SMANIO, Gianpaolo Poggio; BERTOLIN, Patrícia Tuma Martins; BRASIL, Patrícia Cristina (Orgs.). O Direito na Fronteira das Políticas Públicas. Páginas\&Letras, 2015, p.23.

6 BAUMAN, Zygmunt. Vigilância Líquida. Jorge Zahar. 2013, passim. 
Within this context, questions, controversies, and conflicts regarding public security actions and institutions increase concomitantly, especially those related to policing and police authority ${ }^{7}$. Police can be understood as a military or civil institution that has an organized personnel body with obligations, including the crime control and public order maintenance, even if physical force must be used ${ }^{8}$. These obligations were authorized by the society and respective governments and were applied to these people?.

The Brazilian military police model dates back from the arrival of the Second Line of auxiliary troops, in the Lisbon standards ${ }^{10}$. The police structure has two forces, one civil and another military, a model that has persisted more clearly since the arrival of the Royal Family ${ }^{11}$. The policing mandate can be understood as "the exercise of coercive power legitimately and legally backed by the force" ${ }^{12}$. The police power

7 LEMES, Thiago Morais de Almeida e GARRIDO, Rodrigo Grazinoli. Transformações das instituições de segurança pùblica brasileira e seus reflexos no reconhecimento do mandato e na accountability. Revista Direito \& Paz. v. 1, n. 36, 2017, p.218.

8 BITTNER, Egon. The Functions of Police in Modern Society. A Review of Background Factors, Current Practices, and Posible Role Models. New York. Janson Aronson, 1975, passim.

9 BAYLEY, David Hume. Comparando a Organização das Polícias em Países de Língua Inglesa. In: Tonry, Michael \& Morris, Norval (eds). Policiamento Moderno. São Paulo, Editora USP, 2003, p. 539. CARRABINE, Eamonn; COX, Pam; LEE, Maggy; PLUMMER, Ken. e SOUTH, Nigel. Criminology: A Sociological Introduction. Routledge, 2009, p.338. MUNIZ, Jaqueline de Oliveira. e PROENÇA Jr. D. Da Accountability Seletiva à Plena Responsabilidade Policial. In: CRUSO, Haydée; MUNIZ, Jaqueline e CARBALLO e BLANCO, Antônio Carlos Carballo (Org.). Polícia, Estado e Sociedade: Saberes e Práticas Latino-americanos. 1 ed. Rio de Janeiro: Publit Seleções Editoriais, 2007, v. 1, p. 25.

COMISSÃO DA VERDADE - ESTADO DE SÃO PAULO. Relatório. Tomo 1, Parte 1 - estruturas e sistemas da repressão. A militarização da segurança pública. 2015.

11 For more information about structure and history of Brazilian Police Institutions, see: LEMES, Thiago Morais de Almeida e GARRIDO, Rodrigo Grazinoli. Transformações das instituições de segurançapública brasileira e seus reflexos no reconhecimento do mandato e na accountability. Revista Direito \& Paz. v. 1, n. 36, 2017

12 Ibdem, p.38. 
as defined by the National Tax Code (Law n ${ }^{\circ} 5172 / 1966$ ) should not be thwarted, but it can be interpreted from the following wording:

Art. 78. The police power is deemed as a public administration activity that, limiting or disciplining right, interest or freedom, regulates the practice of an act or abstention of a fact, by virtue of public interest related to safety, hygiene, order, customs, discipline of production and market, the exercise of economic activities which are dependent upon concession or authorization by the Public Power for public peace or for the respect for property and individual or collective rights.

Certainly, the policing mandate not always was developed to serve the citizen but, above all, towards the fulfillment of specific political interests ${ }^{13}$ That way, even in a democratic society, tensions and contradictions remain to be solved in this action.

Also, democratic and citizen actions should not be confused with neglect of the use of force, but rather the qualitative differences between force and violence must be underscored. Police action is fundamentally based on the use of force, within legality and legitimacy ${ }^{14}$. Thus, the policing mandate has to be an instrument of conflict management and coercion limited by legislation and social legitimacy.

Lastly, among the apparent contradictions of democratic police action are the limits of discretion. Police action should not be restricted as discretion is required to act differently in each case, demanding immediate and emergency decisions ${ }^{15}$. As a result, the police will always be like a "glass" waiting for the "stones" to be shattered. This subtle irony

13 LEMES, Thiago Morais de Almeida e GARRIDO, Rodrigo Grazinoli. Transformações das instituições de segurança pùblica brasileira e seus reflexos no reconhecimento do mandato e na accountability. Revista Direito \& Paz. v. 1, n. 36, 2017, p. 228.

14 MUNIZ, Jaqueline de Oliveira. e PROENÇA Jr. D. Da Accountability Seletiva à Plena Responsabilidade Policial. In: CRUSO, Haydée; MUNIZ, Jaqueline e CARBALLO e BLANCO, Antônio Carlos Carballo (Org.). Polícia, Estado e Sociedade: Saberes e Práticas Latino-americanos. 1 ed. Rio de Janeiro: Publit Seleções Editoriais, 2007, v. 1, passim.

15 Ibdem, p.41. 
was well established by Marx ${ }^{16}$ : "the police become both the main support and the main threat to a democratic society".

The training of Brazilian police officers is by far still part of a repressive proposal, based on criminal punitivism, militarism, and under a dogmatic vision typical of bachelorism ${ }^{17,18,19,20,21}$.

Kant de Lima points out that this training, focused on obedience to the rigid canons of law and hierarchy relations between positions, reveals to be:

[...]distanced from the essential for a good performance of police functions, which consists of making real-time, autonomous, and independent decisions subjected to further liability, which include an unpredictable variety of issues that are delivered. ${ }^{22}$.

This lack of preparation for reality often leads the officers to go beyond the limits of law on behalf of "defense of public order" for believing in a clear division between citizens and enemies of society ${ }^{23}$. According to Rodrigues, the military police training is based on a model

16 MARX, Gary T. Police and Democracy. In: Amir, M e Einstein, S. (eds.) Policing, Security and Democracy: Theory and Practice, vol. 2. Office of International Criminal Justice. 2001. online.

17 BUARQUE DE HOLANDA, Sergio. Raízes do Brasil. 26a ed. São Paulo: Companhia das Letras, 1995. p.156.

18 KANT de LIMA, Roberto. Entre as leis e as normas: Éticas corporativas e práticas profissionais na segurança pública e na Justiça Criminal. DILEMAS. Vol. 6 - n 4, 2, 2013, p. 564.

19 RODRIGUES, R The Dilemmas of Pacification: News of War and Peace in the 'Marvelous City'. Stability: International Journal of Security \& Development, 3(1): 22, 2014, passim.

20 FRANÇA, F.G. Pensar ou Obedecer? - Desafio da educação em direitos humanos para os policiais militares. Revista Interdisciplinar de Direitso Humanos. V.4, n.1, 2016, p.75,

21 MUNIZ, Jaqueline de Oliveira. A Crise de Identidade das Polícia Militares Brasileiras: Dilemas e Paradoxos da Formação Educacional. Security and Defense Studies Review. V. 1, 2001, p.186.

22 Idem 18.

23 KANT de LIMA, Roberto. Ensaios de antropologia e de direito: Acesso à justiça e processos institucionais de administração de conflitos e produção da verdade jurídica em uma perspectiva comparada. Rio de Janeiro: Lumen Juris. 2011. 289p. 
which reflects that "the development of individual leadership in a dialogic scenario that would be necessary for peace is not prioritized." ${ }^{4}$

Indeed, this way of acting, which has historical roots, served the political interests of governments and was legitimized by a large part of the population, and persists as a form of social and crime control ${ }^{25}$.. De Lima, citing other authors, made it even clearer in a passage that deserves to be quoted:

[...] the persistence of police violence, for instance, could be partly linked to the popular support given to police actions, demonstrating a cultural pattern widespread, which legitimizes the use violence by authorities. As police behavior appears to be in line with acceptable standards for most people, there would be some reluctance to support attempts at change towards the strengthening of the rule of law and respect for individual rights ${ }^{26}$.

Such modus operandi can be well explained by the data from the $11^{\text {th }}$ Brazilian Public Safety Yearbook ${ }^{27}$, wherein it is stated that between 2009 and 2016, there were 21,897 deaths during police operations. According to data from 2016, this situation brings fear to the majority of population to be victims of such violence, by either the Military Police (59\%) or the Civil Police (53\%). Overall, $70 \%$ of the population believes that police officers overuse power. The recognition of the mandate is also related to the death of police officers. Brazilian police officers died 113\% more on duty than did American police officers between 2009 and 2015; in 2016 alone, 437 police officers were murdered..$^{28}$

Now, if even constitutional agents of public security (federal, civil and military police officers and military firefighters) are harshly

24 Ibdem 19, p 10.

25 Idem 23.

26 LIMA, João Marcelo Maciel. Democracia e accountability: mecanismos de controle externo na polícia militar do estado de São Paulo (1989-2007). AURORA. II(3), p. 56-69, 2008, p. 59.

27 FÓRUM BRASILEIRO DE SEGURANÇA PÚBLICA. $11^{\circ}$ Anuário Brasileiro de Segurança Pública. 2017. p. 107.

28 FÓRUM BRASILEIRO DE SEGURANÇA PÚBLICA. $10^{\circ}$ Anuário Brasileiro de Segurança Pública. 2016, p. 6. 
criticized, despite their problems in professional training and performance, and instructions of acting in public safety as the first mission, what can we say about the performance of Armed Forces agents in this context? For these, the mission of public security, by the assurance of law and order, is only secondary ${ }^{29}$.

\section{Agents of The Armed Forces, the Military Staff}

According to the definition found in the Aurélio Portuguese Dictionary, a military officer is someone who is taking part of "the Army's career", participating in "wars", "battles", among others.

In turn, the Military Penal Code brings a legal concept for it in its article 22, adding that "a serviceperson is [...] anyone who, in time of peace or war, is incorporated into the Armed Forces to serve in all ranks and grades, or subjection to military discipline". While the article 142 of the Federal Constitution, specifically at $\S 3$, determines that "the members of the Armed Forces are military officers".

Nevertheless, as regards to Public Security, article $144^{30}$ of the Federal Constitution brings the figure of Military Police and Fire Brigade, which, in turn, are incorporated into the Armed Forces only in case of declared war, to be the so-called Auxiliary Forces and reservations of the Army ${ }^{31}$, also divided into ranks and grades. In this way, the Brazilian Military Forces comprise the Armed Forces along with the State Military Police and Fire Brigade.

That being said, military officers are intended to serve the nation, through federal or state agencies, being a special civil servant (i.e.,

29 Art. 142 c/c art.144, C.F e Lei Complementar no $117 / 2004$.

30 C.F. art. 144 Public security, the duty of the State, the right and responsibility of all, is exercised for the preservation of public order and the security of persons and property, through the following organs: I - federal police; II - federal highway police; III - federal railway police; IV - civil police; V - military police and military fire brigades.

31 C.F. art. 142 The Armed Forces, consisting of the Navy, the Army and the Aeronautics, are permanent and regular national institutions, organized on the basis of hierarchy and discipline, under the supreme authority of the President of the Republic, and are designed to defend The guarantee of constitutional powers and, on the initiative of any of them, of law and order. 
military servant) who, in turn, owns a special status, as in the article 3 of the Law $n^{\circ} 6880 / 80$ of the Military Statute. In litteris: "Due to their constitutional destination, the members of the Armed Forces are part of a special category of Homeland Servants, being named military officers."

About this definition, the honorable Gasparini ${ }^{32}$ provided an explanation of the term 'agents', "stating that military agents are all persons who, permanently or temporarily, perform military activity at the federal or state level, earning a subsidy".

These agents, of both genders, enter the Military Forces through an open call for tender (military career) or by volunteering (summoned, reinstated, designated, or mobilized reserve component), military training students from active- and reserve-duty personnel, every Brazilian citizen mobilized for service in time of war, and people from compulsory military service (recruitment), which occurs through the provision of initial military service ${ }^{33}$.

In turn, it is important to emphasize that the military officers have unique duties and obligations, such as the sacrifice of their own life ${ }^{34}$. They also have rights, prerogatives and obligations assigned them according to their functions within the military hierarchy, whose division is based on ranks and grades or for being (or not) in active service for the Military Forces.

Rank is the hierarchical level of an officer, which is conferred by the President of the Republic for the Armed Forces ${ }^{35}$ and by the Governor

32 GASPARINI, Diogenes. Direito Administrativo. $17^{\mathrm{a}}$ ed. São Paulo: Saraiva, 2012. p.309.

33 Army recruitment is mandatory only for males above 18 years old, or for those who have a higher education degree of interest in the military administration (medical, veterinary, pharmacy, and nursing professionals). These people got rid of compulsory service at enrollment for being during academic formation, to do so later within their respective field of expertise.

${ }_{34}$ Lei $n^{0} 6.880 / 1980$. art. 27. Art. 27. There are essential manifestations of the military value: I - patriotism, translated by the unwavering will to perform military duty and by the solemn oath of fidelity to the Motherland even with the sacrifice of one's life; II - civility and the cult of historical traditions; III faith in the high mission of the Armed Forces; IV - the spirit of body, pride of the military by the organization where it serves; $\mathrm{V}$ - the love of the profession of arms and the enthusiasm with which it is exercised; and VI - the technical and professional improvement.

35 C.F. art. $142 \S 3^{\circ} \mathrm{I}$. 
of the respective member state and Federal District for the Military Police and Fire Brigade ${ }^{36}$. Yet the grade is the hierarchical degree of the military base, which is vested by a competent military authority ${ }^{37}$.

Concerning the military activity or inactivity, the active military is known, by law, to be the person who is serving the Armed Forces or the State Military Forces, as well as those of the Federal District, ready to fulfill their constitutional functions and being in continuous activity and entirely devoted to the Military Forces. In the $\S 1$ of the article 3 , from the Military Statute, it is foreseen that active military people may be:

I - professional soldier; II - incorporated soldier to provide initial military service during periods foreseen by legislation or extensions; III - members of the Armed Forces Reserve when summoned, reinstated, designated or mobilized; IV - students of a military training body of active- and reserve-duty personnel; and $\mathrm{V}$ - in time of war, every Brazilian citizen mobilized for service in the Armed Forces.

Next comes the figure of an inactive military person, who is in remunerated reserve, retired or in both categories, exceptionally (fulfilling task for a certain time after reservation), as stated in paragraph "b" of $\S$ 1 of the article 3, from the Military Statute, as follows:

b) In inactive status:

I - Agents in a remunerated reserve belonging to the Armed Forces and receiving remuneration from the Union, but still subject to the provision of service on active duty, upon summons or mobilization; and II - retired persons that, when had undergone one of the above situations, are permanently exempted from active duty, but continue to receive remuneration from the Union.

In addition, those who are considered military officers are required dedication and continuous improvement through continuous and entirely devoted activity in favor of the primary purposes of the Military Forces, as well as intellectual capacity, physical ability, and moral reputation.

\footnotetext{
36 C.F. art $144 \S 6^{\circ}$.

37 Lei $n^{\circ} 6.880 / 1980$, art $16 \S 3^{\circ}$.
} 


\section{Operations of Law and Order (LAO)}

As taught by Agra ${ }^{38}$, the Armed Forces, composed of the Brazilian Navy, Army, and Air Force, "are the contingent of men whose primary prerogative is the Nation's defense, noting that these three forces have relative autonomy, following the guidelines formulated by the Ministry of Defense".

The Federal Constitution, in turn, besides conferring the task of defending the country on the Armed Forces, it establishes their responsibilities, specifically in the article 142 , such as "the guarantee of constitutional powers and, by the initiative of any of these, of the law and order". Therefore, besides being based on principles, as will be seen from now on, the Armed Forces have attributions both in an external and internal sphere of our territorial delineations.

Abroad, the Armed Forces were given responsibility of maintaining the National Security and Sovereignty, ensuring the defense against threats from other States, as guardian of the Brazilian territory. In the National Defense field, the Armed Forces are supposed to protect the Brazilian population and look after national interests, protecting the country against any kind of threat that may harm its sovereignty. Furthermore, Hely Lopes Meirelles ${ }^{39}$ emphasizes that "National Security is an integral and permanent surveillance of the State over its territory, safeguarding the people, its political regime and institutions".

On the other hand, within a national scope, on continuance and regularity matters, "the forces are permanently disposed since they are linked to the very existence of the State, and cannot be dissolved for functioning continuously" ${ }^{\prime 0}$. Thus, the Armed Forces will also be in charge of ensuring the constitutional powers, when requested, and mainly by means of request, interventions would occur, but in due course of time in very special situations ${ }^{41}$.

38 AGRA, Walber de Moura. Curso de Direito Constitucional. $8^{\text {a }}$ ed. Rio de Janeiro: Forense, 2014. p. 775.

39 MEIRELLES, Hely Lopes. Direito Administrativo Brasileiro. 25a Edição. São Paulo: Malheiros, 1996.

40 AGRA, Walber de Moura. Curso de Direito Constitucional. $8^{\text {a }}$ ed. Rio de Janeiro: Forense, 2014. p. 775.

41 C.F. art. 142. 
This competence, called the Law and Order Operation (LAO), is signed in a subsidiary and interventional action, initiated by the President of the Republic or in response to a request made by any of the constitutional powers, through the Presidents of the Supreme Federal Court, the Federal Senate, or the House of Representatives.

This is not a recent action, it could have been seen more or less clearly since the constitution of $1824^{42}$. However, since the Constitution of 1988, it became more explicit especially in the assumptions expressed in articles 34 (Federal Intervention), 136 (State of National Defense), and 137 (State of Siege), as well as in the article 15 of Complementary Law $n^{\circ}$ 97/99.

In the first assumptions (federal intervention; state of defense; state of siege), there is a direct interference with the exercise of fundamental rights and autonomy by Federation Units. In the other three, the same is not true. Specifically, in nationally relevant events, the role of the Armed Forces in Public Security is regulated by the article 5, sole paragraph of Decree $n^{0} 3,897 / 01$, wherein the military officers "are entrusted to network with local authorities". In addition, the role in policing work requested by the State Governor is regulated by the Complementary Law $n^{0} 97 / 99$, with wording modified by the Complementary Law $n^{0} 117 / 2004$.

In spite of the lack of exceptions, to fulfill the demands for the action of the Armed Forces in Public Security, all the instruments for the preservation of the public order and the safety of people and property must be exhausted, or being unable to be employed. However, such joint action with military forces, instead of being occasional and of short duration, has been reiterated and for an indefinite period.

According to Barroso ${ }^{43}$, the most common ways of joining the Union and the states for the action of the Armed Forces have not been

42 LIMA e SILVA, Gualterberg Nogueira e SCHWARTZ, Germano André Doederlein. Espaço urbano e cultura do medo: o uso das forças em atividade de polícia. Reflexão dogmática sobre a pacificação nas comunidades brasileiras. In: SANTOS, Bartira Macedo Miranda; RIBEIRO, Luiz Gustavo Gonçalves e De MELLO, Marilia Montenegro Pessoa. Criminologias e política criminal. Florianópolis: CONPEDI. 2015. p. 347.

43 BARROSO, Luís. Roberto. Segurança pública: atuação das Forças Armadas tem de ser excepcional. Consultor Jurídico, 26 jun. 2008. 
through agreements. This is, however, a means of regulating short-term actions used, for example, in stoppages by Military Police staff in Tocantins, Alagoas, Minas Gerais, Paraíba, Pernambuco and, more recently, Espírito Santo states.

Therefore, only in the 2010 decade, still underway, the Presidency of the Republic decreed LAO operations almost 30 times, which cost R $\$ 1.4$ billion. By comparison, between 2011 and 2015, presidential expenses with the National Public Security Secretariat did not exceed R\$ 49.9 million $^{44}$.

For Machado ${ }^{45}$, the political choice to militarize public security has become quite evident in recent years. This author also reports that, only in 2017, the following LAO operations were decreed:

Rio de Janeiro (July 28 to December 31, 2017), Federal District (Esplanade of Ministries; May 24 to 25, 2017), Espírito Santo (February 6 to March 8, 2017), Greater Rio de Janeiro (February 14 to 22, 2017), Espírito Santo (February 6 to 16, 2017), Greater Natal (January 20 to February 4, 2017), and throughout the entire Brazilian Prison System (from January 17, 2017 to January 17, 2018).

In the last days of December 2017, the government enacted another LAO operation; sending two thousand men from the Armed Forces to Rio Grande do Norte, initially for a fortnight ${ }^{46}$. This operation was due to a strike by the state police officers over unpaid wages and poor work conditions.

Of course, public safety is everyone's right and state's responsibility, being embodied by the exercise of police power involving any action for public safety (article 144 of the Federal Constitution). However, among the public agencies responsible for public safety would be the Police, whether Federal Police, Federal Highway or Federal Railway Patrols,

44 CABALlERO, M. Diagnóstico Reação em Vez de Prevenção. A Guerra do Brasil. Jornal O Globo. 14 de dezembro de 2017, p. 8.

45 MACHADO, Leonardo Marcondes. Lei 13.491/17 e a militarização da segurança pública. In: FONTES, Eduardo e HOFFMANN, Henrique. Temas avançados de polícia judiciária. Salvador: JusPodium. 2018, passim.

46 Decreto de 29 de dezembro de 2017. 
as well as Civil and Military Police, of the responsibility of each state of the Federation, in addition to the Fire Brigade, which are all, intended to preserve or restore public order, and population property and well-being.

First of all, the Armed Forces are clearly not part of any body whose attribution is the exercise of activities related to public security, not least since there is an own chapter in the Federal Constitution about it. Thus, given its nature and constitutional mission, the Armed Forces can only be involved in public security in cases of article 15 of Complementary Law $n^{\circ} 97 / 99$, when they would take the lead in public security bodies and work to restore order, as well as federal intervention in the member states of the Federation ${ }^{47}$.

Notably, the intervention cited in the Complementary Law No. 97 of June 9, 1999, which was later amended by the Complementary Law No. 117 of September 2, 2004, provides for general rules for organization, preparation, and employment of the Armed Forces, explaining in the article 15 under which conditions the Armed Forces are to act to guarantee law and order ${ }^{48}$.

47 FELIZARDO, Marília do Amaral e Do AMARAL, Vilma Aparecida. Da atuação das forças armadas na segurança pública dos estados-membros. Revista de Direito Público, V, 4, N. 2, 2009, p.79.

48 Art. 15. The Federal President shall be responsible for engaging the Armed Forces in the country's defense and for constitutional guarantees of power in the participation of law and order and peace operations. The President directs the State Minister of Defense, who shall activate the operational bodies, as the following hierarchy: I - directly to the Supreme Commander, in the case of Combined Commands, composed by means adjudicated by the Armed Forces and, when necessary, by other organs; II - directly to the State Minister of Defense, for training purposes, in combined operations, or when it is considered the Brazilian participation in peace operations; III - directly to the respective Force Commander, respecting the superior direction of the State Minister of Defense, in the case of isolated employment of means of a single Force.

$\S 1^{\circ}$ The President of the Republic shall decide whether to use the Armed Forces, on his own initiative or in response to requests from the Presidents of Federal Supreme Court, Federal Senate, or House of Representatives. The President directs the State Minister of Defense, who shall activate the operational bodies, as the following hierarchy:

§o To ensure law and order, the Armed Forces, at the initiative of any of the constitutional powers, shall act as the guidelines issued in the act of the Federal President, after depleting the instruments for preservation of 
Currently, the law has not been reliably observed. Over time, although the Armed Forces have been used in situations that have already reached a high degree of conflict, there has been a glimpse of trivialization of military employment, repeatedly, for unlimited time, often as a way increase the scarce contingent of state police.

In this regard, we can first cite the support given to political events such as ECO-92 in $1992^{49}$; OPERAÇÃO RIO II in 1995; municipal or national elections ${ }^{50}$; and to sporting events such as the Confederations Cup and the World Cup, both in $2014^{51}$; in addition to the Olympic Games hosted in Brazil in 2016 2 .

In the so-called "occupations", such as those that took place in Rio de Janeiro at different times, like in Mangueira and Dendê slums in 1994, Rocinha in 2011, Complexo do Alemão in 2010, and Complexo da Maré in 2014, the Armed Forces were used as a state's response to its own ineffectiveness in tackling crime, which reached alarming levels.

The latest cases of use of the Armed Forces outside of the constitutional scope have occurred in support of prisons. Only in the first quarter of 2017, several prisoner rebellions culminated in the death of

public order and people property and well-being listed in article 144 of the Federal Constitution.

$\S 30$ The instruments listed in the article 144, Federal Constitution, are considered exhausted when, at a given moment, they are formally recognized by the respective Federal or State Executive Chief as unavailable, inexistent or insufficient to the regular performance of a constitutional mission.

$\S 40$ If fulfilled the conditions in $\S 30$ of this article, after message of the Federal President, operational bodies of the Armed Forces will be activated, which will develop, at times in a previously established area and for a limited time, preventive and repressive actions required to ensure the result of law and order operations.

$\S 50$ Once the Armed Forces are designated for law and order operations, the competent authorities should transfer, through a formal act, the operational control of public security bodies to the new authority in charge; so coordination centers for operations are formed, being composed of representatives of public bodies, under its operational control or with related interests.

49 Lei Complementar $n^{\circ}$ 69/1991.

50 Lei $n^{\circ} 4.737 / 1965$, art- 23, XIV.

51 Lei $n^{\circ} 12.663 / 2012$.

52 Decreto de 24 de agosto de 2016. 
dozens of inmates in different states of the Federation, such as Amazonas, Roraima, São Paulo, and Rio Grande do Norte.

It is unambiguously that the use of the Armed Forces has become a recurrent and trivial tool, which does not tackle the root of the problem, but presents a fast and media solution, using the population confidence as sedative against problems with the growing criminality and wishes for effective responses by the State.

The ordinary use of the Armed Forces denotes the lack of investments in public security and politicizing the issue. Thus, such a choice demonstrates that there is no intent of improvements to assure social peace, increasing the Union's interference with states' affairs and threatening the federative pact.

\section{Militarization of Public Security and Human Rights}

The use of Armed Forces in Public Security should occur only in exceptional situations, because when enforcement of these agents is reiterated in the form of Complementary Law No. 117/2004, it is possible to endanger the entire State framework.

Felizardo and Do Amararal point out the following consequences of this action:

[...] weakening of the democratic rule of law; disharmony among the three government branches; imbalance of the federative pact; state of chaos; disintegration of the fundamental rights; and small share of the Public Security organs already responsible for the safety of Member States ${ }^{53}$.

It should be clear that the constitutional use of the Armed Forces is not being discussed here, but rather the suitability and preparation of agents. According to Flavia Piovesan, prior to take any measure, it is needed to "respect the legal principles of reasonableness, proportionality,

53 FELIZARDO, Marília do Amaral e Do AMARAL, Vilma Aparecida. Da atuação das forças armadas na segurança pública dos estados-membros. Revista de Direito Público, V, 4, N. 2, 2009, p. 79. 
and necessity to avoid that any federal decree or intervention provides the possibility of a State acting under principles of authoritarianism" ${ }^{54}$.

Therefore, the confrontational and territorial domination politics have been worsened with clear perspective of militarization, where a criminal is the enemy, instead of encouraging a criminal investigation ${ }^{55}$. In general, these authors consider that "[...] the use of unprepared or malformed military forces can seriously jeopardize the rights to democracy, freedom, and life" ${ }^{56}$. The death of three young people in Morro da Providência (Rio de Janeiro) in 2008, during a military action, is an example of this ${ }^{57}$.

The recurrence of LAO operations led to submission and approval of an amendment of the Military Penal Code ${ }^{58}$. A representative of the Liberal Party (PL), Mr. Esperidião Amin, presented the law project to the House of Representatives and Senate. It empowered the Union Military Justice to judge intentional crimes against the life of soldiers involved in these operations against civilians if under the following conditions:

I - the fulfillment of duties as established by the President or the State Minister of Defense;

II - action involving the security of a military institution or mission, even if non-belligerent; or

III - activities of military nature, peace operations, law and order assurance or subsidiary attribution, which are performed in accordance with provisions stated in article 142 of the Federal

54 PIOVESAN, Flávia. apud De LIMA e SILVA, Gualterberg Nogueira e SCHWARTZ, Germano André Doederlein. Espaço urbano e cultura do medo: o uso das forças em atividade de polícia. Reflexão dogmática sobre a pacificação nas comunidades brasileiras. In: SANTOS, Bartira Macedo Miranda; RIBEIRO, Luiz Gustavo Gonçalves e De MELLO, Marilia Montenegro Pessoa. Criminologias e política criminal. Florianópolis: CONPEDI. 2015. p. 352.

55 FELIZARDO, Marília do Amaral e Do AMARAL, Vilma Aparecida. Revista de Direito Público, V, 4, N. 2, 2009, p. 92.

56 Ibdem, p. 94.

57 G1. Especialista teme que morte de jovens da Providência fique impune.

58 PLC 44/2016 (PL 5768/2016). Justification [...] It should be noted that the Armed Forces are increasingly presente in the national scene acting close to society, especially in operations to guarantee the law and order. [...] 
Constitution, and other information required by the following law codes:

a) Brazilian Air Force Code;

b) Complementary Law no 97, of June 9, 1999;

c) Military Code of Criminal Procedure; and

d) Electoral Code.

Several politicians and public security professionals commented on complementary law project (PLC 44/2016) in O Dia newspaper ${ }^{59}$. The Senate Rapporteur, Senator Pedro Chaves, considered that, while in military action, these agents are the State itself, and it is impossible to judge them as regular citizens. Yet Senator Romario, who voted in favor of the project, considered that the Armed Forces have been increasingly used in such operations, so the Military Justice would be a more specialized body with specific knowledge for this kind of trials. The lawyer, Marcelo Knopfelmacher, acknowledged that the new legislation would bring greater security to the Armed Forces. In addition, Paulo Storani, former Captain of the PMRJ (Rio de Janeiro's Military Police), stressed that the Military Justice will never be corporatist, but on the contrary, it is much more rigid than is ordinary justice ${ }^{60}$.

A contrary view was highlighted by Ignácio Cano, a professor at UFRJ (Federal University of Rio de Janeiro), who considered it a contradiction the jurisdiction of military soldiers from the Public Security, such as state and district police forces, but judging them by another court $^{61}$. The lawyer, João Tancredo, considered this measure a great step backwards, besides stating that this type of exception has already been proven to be unsuccessful in the military dictatorship ${ }^{62}$. The human rights advisor of Amnesty International Brazil, Renata Neder, believes that this legislation will encourage practices of extrajudicial executions,

59 SANTANA, Matheus. Militar julgar militar: especialistas veem risco de corporativismo. O Dia de 15 de outubro de 2017.

60 Idem.

61 Idem.

62 Idem. 
as the actions of the Armed Forces in Public Security have historically violated the Human Rights ${ }^{63}$. Amnesty International has launched an urgent campaign "VETA TEMER: crimes against life must be tried in civilian courts, prevent such setback!” ${ }^{4}$.

Whether by the lack of legal warranties or unsuitableness, even the Army personnel feel uncomfortable participating in LAO operations. The Commander of the Land Forces, General Eduardo Villas-Boas, made this clear in a public hearing at the Senate Committee on Foreign Relations and Defense. At this time, the Commander criticized part of the population that demands military intervention to solve political crises ${ }^{65}$.

Despite the diverse opinions, which could lead to further discussions, on October 13 of 2017, President Temer sanctioned the Law $\mathrm{n}^{\circ}$ $13491 / 17$, with the amendments to the Military Penal Code, as proposed by the PLC $44 / 2016$.

It should be borne in mind that, if for some changes in military criminal legislation would give legal security for soldiers employed in public security operations, the continuous use of the Armed Forces as police outside the barracks gives rise to a myriad of new situations of conflict, thus raising the questioning about this legislation.

Indeed, discussions on the limits of the military penal code are not restricted to Brazil. As for the degree of military jurisdiction over civilians, nations are divided into four categories:

a) countries where military courts have jurisdiction only during the war period (Austria, Denmark, Finland, Germany, Norway and Sweden): b) countries where military courts have jurisdiction both in time of war and in time of peace, but cannot judge civilians (England and the United States); c) countries permitting civilians to be tried by military courts, but only in case of crimes against the external security of the country or the Armed Forces

63 Idem.

64 ANISTIA INTERNACIONAL. Assine agora a Ação Urgente VETA TEMER: crimes contra a vida devem ser julgados na justiça comum e impeça mais esse retrocesso!

65 LEON, Lucas Pordeus. Comandante do Exército critica uso das Forças Armadas para garantia da lei e da ordem. Radio Agência Nacional. 
(France, Italy, Argentina, and Uruguay), or during a state of siege (Colombia), or for terrorism crimes (Peru): d) countries that adopt a broad military jurisdiction over civilians in peacetime (Franco's Spain, Pinochet's Chile, Marcos's Philippines during martial law of 1974-81, and Brazil, even after the "Citizen" Constitution of $1988^{66}$.

As Military Justice Jurisdiction varies with each country, the related cases occupied about $11 \%$ of the total number of crime cases reaching the International Court of Human Rights. Overall, the Court recognizes that there are still some challenges to be overcome by the Military Justice to ensure the human rights. These include the right to a due process, an effective judicial protection, and the duty to investigate and prosecute those responsible for human rights violations ${ }^{67}$.

In seeking standards that limit the military justice action internationally, it must be deemed a restrictive military jurisdiction scope, besides special or exceptional, excluding civilian trials and those of military personnel directly involved in minor crimes, directly related to the military order ${ }^{68}$. Zaverucha and Melo Filho ${ }^{69}$ considered that only countries that strictly follow these precepts would be democratic, being unjustifiable the exceptions found in the Brazilian Military Justice Code.

A more detailed analysis on international jurisprudence was reported in a very complete paper by Rabelo $\mathrm{Neto}^{70}$, who investigated 31 cases tried between 1999 and 2015, by the Inter-American Court of

${ }^{66}$ ZAVERUCHA, Jorge. Military Justice in the State of Pernambuco after the Brazilian Military Regime: An Authoritarian Legacy. Latin American Research Review. Vol. 34, No. 2, 1999. p.43-44.

67 MAG-GREGOR, Eduardo Ferrer. Las siete principales líneas jurisprudenciales de la Corte Interamericana de Derechos Humanos aplicable a la justicia penal. Revista IIDH. Vol. 59, 2014. passim.

${ }_{68}$ Ibdem, p. 80.

69 ZAVERUCHA, Jorge. e MELO FILHO, Hugo. Justiça Militar. In: AVRITZER, Leonardo; BIGNOTTO, Newton; GUIMARÃES, Juarez; FILGUEIRAS, Fernando e STARLING, Heloisa. Dimensões Políticas da Justiça. Ed. Civilização Brasileira. p. 421-430, 2017.

70 RABELO NETO, Luiz Octávio. Competência da justiça militar da união para julgamento de civis: compatibilidade constitucional e com o sistema interamericano de proteção de direitos humanos. Revista de Doutrina e Jurisprudência do Superior Tribunal Militar. V.25, n.2, 201. 2016. p. 119. 
Human Rights (ICHR). According to this author, the ICHR considered the Military Court unable to judge civilian cases in 27 out of those, once it would infringe the legally binding principle of natural justice. Hence, the process would be rigged from the beginning and, thus, the ICHR avoided mentioning the defendant. In one of these cases, the ICHR considered the Military Justice partially and without independence.

With respect to jurisprudence, the author, specifically regarding the Brazilian Military Justice, does not rule out the possibility of the Military Justice judging civilians. However, he points out that, for an independent and impartial jurisdiction, in these cases, the military officers that are members of the Justice Council should not take part in trials ${ }^{71}$.

\section{Conclusion}

Discussions on the use of the Armed Forces in public security should not be restricted to issues of "on the edge" of the public security system, that is, the ostensive ways of solving conflicts in peacetime, when in direct contact with civil society. In fact, such discussions should encompass military action throughout criminal prosecution. Thus, it should be analyzed the employment of the Judicial Police, the Military Public Ministry, and, above all, the Military Justice of the Union and of the States, in jurisdictionally on cases involving civilians and military officers who practice crimes that would not fit, in principle, among those who face administration and military hierarchy and discipline.

If these limits are not observed, the use of the Armed Forces is likely to violate human rights, hence, overcoming the defenses of democratic ideology. Thus, by further expanding the interpretation of what is considered a military crime, with an enlarged military courts jurisdiction over civilians, Brazil runs to enter in a dangerous exception state. In addition, applying the military personnel recurrently in LAO actions to solve the public security irregularities in federation units, despite recognizing vulnerable States, jeopardize the federative pact.

71 RABELO NETO, Luiz Octávio. Competência da justiça militar da união para julgamento de civis: compatibilidade constitucional e com o sistema interamericano de proteção de direitos humanos. Revista de Doutrina e Jurisprudência do Superior Tribunal Militar. V.25, n.2, 201. 2016. p. 135. 


\section{References}

ANISTIA INTERNACIONAL. Assine agora a Ação Urgente VETA TEMER: crimes contra a vida devem ser julgados na justiça comum e impeça mais esse retrocesso! Disponível em: https://anistia.org.br/entre-em-acao/email/acao-urgente-vetatemer-crimes-contra-vida-devem-ser-julgados-na-justica-comum/. Aceso em: 15 out 2017.

AGRA, Walber de Moura. Curso de Direito Constitucional. $8^{\text {a }}$ ed. Rio de Janeiro: Forense, 2014.

BARROSO, Luís. Roberto. Segurança pública: atuação das Forças Armadas tem de ser excepcional. Consultor Jurídico, 26 jun. 2008. Disponível em: <http://www. conjur.com.br/static/text/67573,1>. Acesso em: 10 maio 2008.

BAUMAN, Zygmunt. Vigilância Líquida. Jorge Zahar. 2013.

BAYLEY, David Hume. Comparando a Organização das Polícias em Países de Língua Inglesa. In: Tonry, Michael \& Morris, Norval (eds). Policiamento Moderno, São Paulo: USP, 2003, p. 539-576.

BITTNER, Egon. The Functions of Police in Modern Society. A Review of Background Factors, Current Practices, and Posible Role Models. New York. Janson Aronson, 1975. BUAIZ AMEAÇA PEDRIR INTERVENÇÃO NO ES. Disponível em: <http://www1. folha.uol.com.br/fsp/brasil/fc21119816.htm>. Acessado em 04 de junho de 2017. BUARQUE DE HOLANDA, Sergio. Raízes do Brasil. 26ª ed. São Paulo: Companhia das Letras, 1995.

CABAlLERO, M. Diagnóstico Reação em Vez de Prevenção. A Guerra do Brasil. Jornal O Globo. 14 de dezembro de 2017, p.8

CARRABINE, Eamonn; COX, Pam; LEE, Maggy; PLUMMER, Ken. e SOUTH, Nigel. Criminology: A Sociological Introduction. Routledge, 2009

COMISSÃO DA VERDADE - ESTADO DE SÃO PAULO. Relatório. Tomo 1, Parte 1 - estruturas e sistemas da repressão. A militarização da segurança pública. 2015. Disponível em: http://comissaodaverdade.al.sp.gov.br/relatorio/. Acesso em: 26 ago 2018.

CONFLITO ENTRE PMS DEIXA CINCO FERIDOS. Disponível em: <http:// www1.folha.uol.com.br/fsp/brasil/fc2510200011.htm>. Acessado em 02 de junho de 2017.

De BARROS, Marco Antonio. A lei de Segurança Nacional e a Legislação Penal Militar. Disponível em: <http://www.revistajustitia.com.br/artigos/4714cb.pdf>. Acesso em 16. nov. 2016. 
De FRANÇA, F.G. Pensar ou Obedecer? - Desafio da educação em direitos humanos para os policiais militares. Revista Interdisciplinar de Direitso Humanos. V.4, n.1, p. 63-81, 2016.

De HOLANDA, Aurélio Buarque. Minidicionário Aurélio. $7^{\mathrm{a}}$ ed. Curitiba: Positivo. 2008.

De LIMA, João Marcelo Maciel. Democracia e accountability: mecanismos de controle externo na polícia militar do estado de São Paulo (1989-2007). AURORA. II (3), p. 56-69, 2008.

De LIMA e SILVA, Gualterberg Nogueira e SCHWARTZ, Germano André Doederlein. Espaço urbano e cultura do medo: o uso das forças em atividade de polícia. Reflexão dogmática sobre a pacificação nas comunidades brasileiras. In: SANTOS, Bartira Macedo Miranda; RIBEIRO, Luiz Gustavo Gonçalves e De MELLO, Marilia Montenegro Pessoa. Criminologias e política criminal. Florianópolis: CONPEDI. 2015.p.345-364.

EXÉRCITO VAI AO TOCANTINS PARA CONTER GREVE. Disponível em: < http:// www1.folha.uol.com.br/fsp/cotidian/ff2805200101.htm>. Acessado em 01 de junho de 2017.

FABRETTI, Humberto Barrinuevo. Políticas de segurança Pública: questionamentos preliminares. In: SMANIO, Gianpaolo Poggio; BERTOLIN, Patrícia Tuma Martins; BRASIL, Patricia Cristina (Orgs.). O Direito na Fronteira das Políticas Públicas. Páginas\&Letras, 2015, p.23-27.

FELIZARDO, Marília do Amaral e Do AMARAL, Vilma Aparecida. Da atuação das forças armadas na segurança pública dos estados-membros. Revista de Direito Público, V, 4, N. 2, p. 78-98, 2009.

FÓRUM BRASILEIRO DE SEGURANÇA PÚBLICA. Anuário Brasileiro de Segurança Pública. 2016, 137p.

FÓRUM BRASILEIRO DE SEGURANÇA PÚBLICA. Anuário Brasileiro de Segurança Pública. 2017. 107p.

G1. Especialista teme que morte de jovens da Providência fique impune. Notícia de 01 de jul de 2008. Disponível em: http://g1.globo.com/Noticias/ Rio/0,,MUL632522-5606,00-ESPECIALISTA+TEME+QUE+MORTE+DE+JOVENS+DA+PROVIDENCIA+FIQUE+IMPUNE.html. Acesso em: 26 ago 2018.

GASPARINI, Diogenes. Direito Administrativo. $17^{\mathrm{a}}$ ed. São Paulo: Saraiva, 2012. KANT de LIMA, Roberto. Ensaios de antropologia e de direito: Acesso à justiça e processos institucionais de administração de conflitos e produção da verdade jurídica em uma perspectiva comparada. Rio de Janeiro: Lumen Juris. 2011. 289p. 
KANT de LIMA, Roberto. Entre as leis e as normas: Éticas corporativas e práticas profissionais na segurança pública e na Justiça Criminal. DILEMAS. Vol. 6 - n 4, 2, p. 549-580, 2013.

LEMES, Thiago Morais de Almeida e GARRIDO, Rodrigo Grazinoli. Transformações das instituições de segurança pùblica brasileira e seus reflexos no reconhecimento do mandato e na accountability. Revista Direito \& Paz. v. 1, n. 36, p. 217-233. 2017.

LEON, Lucas Pordeus. Comandante do Exército critica uso das Forças Armadas para garantia da lei e da ordem. Radio Agência Nacional. 22 de junho de 2017. Disponível em: http://radioagencianacional.ebc.com.br. Acesso em: 15 out 2017. MAG-GREGOR, Eduardo Ferrer. Las siete principales líneas jurisprudenciales de la Corte Interamericana de Derechos Humanos aplicable a la justicia penal. Revista IIDH. Vol. 59, p. 28-118, 2014.

MACHADO, Leonardo Marcondes. Lei 13.491/17 e a militarização da segurança pública. In: FONTES, Eduardo e HOFFMANN, Henrique. Temas avançados de polícia judiciária. Salvador: JusPodium. p.161-164, 2018.

MARX, Gary T. Police and Democracy. In: Amir, M e Einstein, S. (eds.) Policing, Security and Democracy: Theory and Practice, vol. 2. Office of International Criminal Justice. 2001. Disponível em: http://web.mit.edu/gtmarx/www/dempol. html. Acessado em: 02 nov 2016.

MEIRELLES, Hely Lopes. Direito Administrativo Brasileiro. 25 a Edição. São Paulo: Malheiros, 1996.

MINISTÉRIO DA DEFESA. DISTRIBUIÇAO DAS OPERAÇÕES DE GLO 1992 - 2018. Disponível em: https://www.defesa.gov.br/arquivos/exercicios_e_operacoes/glo/grafico_por_ano_barras_20180824.pdf. Acessado em: 26 ago 2018. MUNIZ, Jaqueline de Oliveira. A Crise de Identidade das Polícia Militares Brasileiras: Dilemas e Paradoxos da Formação Educacional. Security and Defense Studies Review. V. 1, p. 177-198, 2001.

MUNIZ, Jaqueline de Oliveira. e PROENÇA Jr. D. Da Accountability Seletiva à Plena Responsabilidade Policial. In: CRUSO, Haydée; MUNIZ, Jaqueline e CARBALLO e BLANCO, Antônio Carlos Carballo (Org.). Polícia, Estado e Sociedade: Saberes e Práticas Latino-americanos. 1 ed. Rio de Janeiro: Publit Seleções Editoriais, 2007, v. 1, p. 21-73.

MUNIZ, Jaqueline de Oliveira. Despolitização da segurança pública e seus riscos. In: De SOUZA, Rogério Ferreira e Gracino Jr, Paulo (orgs.). Sociedade em perspectiva: cultura, conflito e identidade. Rio de janeiro: Gramma, 2012. p. 119-134.

RABELO NETO, Luiz Octávio. Competência da justiça militar da união para julgamento de civis: compatibilidade constitucional e com o sistema interamericano 
de proteção de direitos humanos. Revista de Doutrina e Jurisprudência do Superior Tribunal Militar. V.25, n.2, 201. p.53-137. 2016

RODRIGUES, R The Dilemmas of Pacification: News of War and Peace in the 'Marvelous City'. Stability: International Journal of Security \& Development, 3(1): 22, p. 1-16, 2014.

SANTANA, Matheus. Militar julgar militar: especialistas veem risco de corporativismo. O Dia de 15 de outubro de 2017. Disponível em: http://odia.ig.com.br/ brasil/2017-10-15/militar-julgar-militar-especialistas-veem-risco-de-corporativismo.html. Acesso em 15 out 2017.

SCHWARCZ, Lilia M.. e STARLING, Heloisa Maria Murgel. Brasil: uma biografia. Companhia das Letras, 2015.

ZAVERUCHA, Jorge. Military Justice in the State of Pernambuco after the Brazilian Military Regime: An Authoritarian Legacy. Latin American Research Review. Vol. 34, No. 2, p. 43-73, 1999.

ZAVERUCHA, Jorge. e MELO FILHO, Hugo. Justiça Militar. In: AVRITZER, Leonardo; BIGNOTTO, Newton; GUIMARÃES, Juarez; FILGUEIRAS, Fernando e STARLING, Heloisa. Dimensões Políticas da Justiça. Civilização Brasileira. p. 421-430, 2017.

\section{Informações adicionais e declarações dos autores (integridade científica)}

Declaração de conflito de interesses (conflict of interest declaration): os autores confirmam que não há conflitos de interesse na realização das pesquisas expostas e na redação deste artigo.

Declaração de autoria e especificação das contribuições (declaration of authorship): todas e somente as pessoas que atendem os requisitos de autoria deste artigo estão listadas como autores; todos os coautores se responsabilizam integralmente por este trabalho em sua totalidade.

- Rodrigo Grazinoli Garrido: projeto e esboço inicial, levantamento bibliográfico, revisão bibliográfica, redação, revisão crítica com contribuições substanciais, aprovação da versão final. 
- Ana Morell: levantamento bibliográfico, revisão bibliográfica, redação, revisão crítica com contribuições substanciais.

- Silvana Vieira Azevedo: projeto e esboço inicial, levantamento bibliográfico, revisão bibliográfica, redação.

Declaração de ineditismo e originalidade (declaration of originality): os autores asseguram que o texto aqui publicado não foi divulgado anteriormente em outro meio e que futura republicação somente se realizará com a indicação expressa da referência desta publicação original; também atestam que não há plágio de terceiros ou autoplágio.

\section{Dados do processo editorial}

(http://www.ibraspp.com.br/revista/index.php/RBDPP/about/editorialPolicies)

- Recebido em: 26/05/2018

- Controle preliminar e verificação de plágio: 10/06/2018

- Avaliação 1: 14/06/2018

- Avaliação 2: 25/06/2018

- Avaliação 3: 04/07/2018

- Decisão editorial preliminar: 15/08/2018

- Retorno rodada de correções: 08/09/2018

- Decisão editorial final: $12 / 09 / 2018$
Equipe editorial envolvida

- Editor-chefe: 1 (VGV)

- Editor-assistente: 1 (CRG)

- Revisores: 3

\section{COMO CITAR ESTE ARTIGO:}

GARRIDO, Rodrigo G.; MORELL, Ana; AZEVEDO, Silvana V. Armed Forces As Security Agency and The Competence of Military Courts: The Prospect of Democratic Breakdown. Revista Brasileira de Direito Processual Penal, Porto Alegre, vol. 4, n. 3, p. 1249-1274, set./dez. 2018. https://doi.org/10.22197/rbdpp.v4i3.167

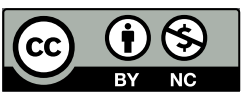

Esta obra está licenciada com uma Licença Creative Commons Atribuição-NãoComercial 4.0 Internacional. 